\title{
Long-Term Variations of Tropospheric Circulations in the Western Pacific Region as Derived from GMS Cloud Winds
}

\author{
By Tsuyoshi Nitta, Taketo Maruyama \\ Meteorological Research Institute, Tsukuba, Ibaraki 305, Japan \\ and \\ Toshihiro Motoki \\ Meteorological Satellite Center, Kiyose, Tokyo 204, Japan \\ (Manuscript received 3 July 1986, in revised form 19 September 1986)
}

\begin{abstract}
Long-term variations of large-scale circulations in the western Pacific regions are investigated by using cloud wind data derived from GMS during 6 years from 1978 to 1984. Comparison between monthly mean winds obtained by the satellite and those by the upper-air sonde observations indicates that upper cloud winds generally correspond to $200-\mathrm{mb}$ winds and lower cloud winds correspond to about $850-\mathrm{mb}$ winds.

6-year averaged monthly mean winds reveal that upper and lower winds in the western Pacific are largely affected by monsoon circulation systems. In the upper troposphere northeasterlies dominate in the equatorial western Pacific to the southeast of the Tibetan High during northern summer, while southeasterlies prevail during winter affected by an anticyclonic circulation generated over the Australian monsoon region.

The first mode of winds obtained by an Empirical Orthogonal Function (EOF) analysis corresponds to wind anomalies associated with the 1982-83 El Niño event. Upper winds and lower winds of this eigenvector suggest that there exists a large-scale east-west circulation with rising motion in the eastern Pacific and sinking motion in the western Pacific. The first eigenvector also possesses an upper cyclonic anomaly circulation in the western Pacific subtropics.

Wind anomalies corresponding to the western Pacific - Japan oscillation of the heat source found by Nitta (1986) are obtained by both EOF and composite analyses. When convective activities are intense in the western Pacific subtropics near $20^{\circ} \mathrm{N}$, an upper cyclonic sell is found to the northwest of the heat source center and an anticyclonic cell appears north of the cyclonic cell. It is suggested that these anomaly circulations might have strong influence on large-scale summer-time circulations in the East Asia.
\end{abstract}

\section{Introduction}

Recent observational and theoretical studies have shown that long-term variations of tropical heat sources play a significant impact in globalscale atmospheric circulations as typically experienced in the 1982-83 El Niño event. The tropical western Pacific is one of key regions for the long-term variations of atmosphere, because larger amounts of precipitation occur all the year round in this region than other tropical regions. Nitta (1986, hereafter referred to as $\mathrm{N})$ analyzed spatial and temporal variations of heat sources in the western Pacific region using cloud amount data for 6 years derived from Geostationary Meteorological Satellite (GMS) and found that there exist two types of dominant heat source anomaly patterns, i.e., one is 
an east-west oscillation along the equator between the western Pacific and the central Pacific corresponding to $\mathrm{El} \mathrm{Niño}$ and the other is a north-south oscillation between the western Pacific subtropics near $20^{\circ} \mathrm{N}$ and middle latitudes near Japan. The latter oscillation is mostly active during northern summer.

Large-scale atmospheric circulations may vary according to these heat source variations. Anomaly wind fields both in the tropical region and in higher latitudes associated with El Niño and Southern Oscillation (ENSO) have been extensively analyzed by composite studies (Rasmusson and Carpenter, 1982) and by case studies such as in 1982-83 (Quiroz, 1983), but long-term variations due to other tropical heat source anomalies have been poorly clarified. Conventional upper-air observations are very limited over the tropical oceanic areas, but cloud tracking wind data derived from geostationary satellites have been providing valuable information on tropical wind fields.

In this study we attempt to examine characteristic features of long-term variations of tropospheric circulations in the western Pacific region using the satellite derived cloud wind data and to demonstrate the usefulness of cloud wind data for the climatic studies. Circulation anomalies related to the tropical heat source variations will be also detailed.

\section{Data}

Cloud wind data during 6 years from May 1978 through April 1984 derived from GMS are used for anlysis. Cloud winds are routinely obtained twice a day by GMS and their procedures and accuracies were reported by technical reports in Japan Meteorological Satellite Center (Hamada, 1979; Kato, 1980; Ichizawa, 1983; Hamada and Kato, 1984). In this paper montly mean upper and lower winds at $5^{\circ} \times 5^{\circ}$ longitude-latitude grids are obtained by averaging nearby cloud wind data with cloud heights above $400 \mathrm{mb}$ and those below $600 \mathrm{mb}$, respectively. These threshold levels are determined from previous comparative results between cloud winds and radiosonde winds (ex. Hamada, 1982).

Fig. 1 shows 6-year averaged mean distributions of data number within $5^{\circ} \times 5^{\circ}$ boxes per

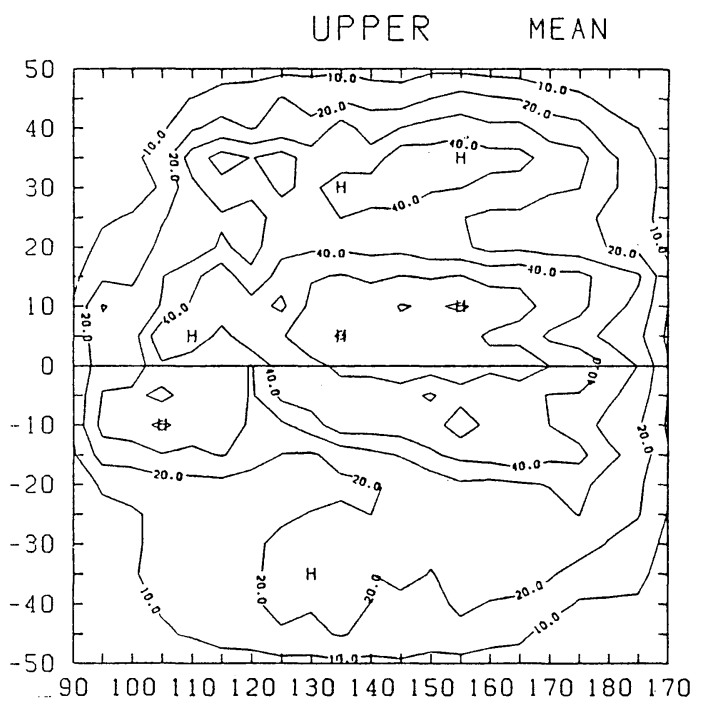

a

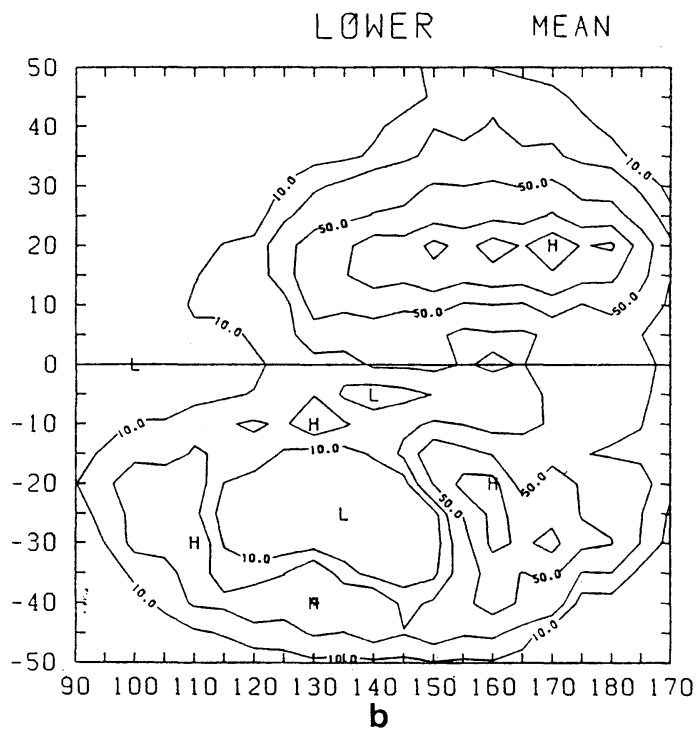

Fig. 1. Mean data number density for (a) upper cloud winds and (b) lower cloud winds. Units are numbers/ $\left(5^{\circ} \times 5^{\circ}\right) /$ month.

month for upper cloud winds and for lower cloud winds, respectively. Since upper cloud winds are usually obtained by cirrus clouds existing in the active convective regions, high data density more than about $40 /$ month is found in the equatorial region between $15^{\circ} \mathrm{S}$ and $15^{\circ} \mathrm{N}$ where Inter-Tropical Convergence Zone (ITCZ) and South Pacific Convergence Zone (SPCZ) are normally located. Although the data density 
for the upper winds decreases in the subtropics and middle latitudes, most of these regions still have higher data density than 20/month. Data density for the lower winds is more localized than for the upper winds. High data densities more than 50/month for lower winds are located in Northern Hemisphere (NH) subtropics to the north of ITCZ and in Southern Hemisphere (SN) subtropics to the south of SPCZ, while low densities are found in the equatorial convective regions because deep cloud clusters overhang low-level tracking clouds. Low-level satellite winds are not derived over the continents and large islands because of effects by surface topography. These distributions of data densities vary seasonally and interannually depending upon temporal and spatial variations of cloud distributions.

By considering the results of comparison between cloud winds and upper-air sonde observations which will be presented in the next section, we used the lower winds in the domain from $125^{\circ} \mathrm{E}$ to $175^{\circ} \mathrm{W}$ and from $30^{\circ} \mathrm{N}$ to $30^{\circ} \mathrm{S}$ and the upper winds from $95^{\circ} \mathrm{E}$ to $175^{\circ} \mathrm{W}$ and from $45^{\circ} \mathrm{N}$ and $45^{\circ} \mathrm{S}$ for analysis, where most of grids have higher data density than about 10-20/ month as shown in Fig. 1.

At first, averaged cloud winds within each $5^{\circ}$ $\times 5^{\circ}$ box for each month are assigned to monthly mean winds at each grid point corresponding to the box center. Then if the number of cloud wind data within the box is less than $10 /$ month, mean winds are recalculated by using cloud winds in wider area so that the total number becomes at least more than 10 . Finally monthly mean winds are obtained at all $5^{\circ} \times 5^{\circ}$ grids in $95^{\circ} \mathrm{E}-175^{\circ} \mathrm{W}, 45^{\circ} \mathrm{N}-45^{\circ} \mathrm{S}$ for upper winds and in $125^{\circ} \mathrm{E}-175^{\circ} \mathrm{W}, 30^{\circ} \mathrm{N}-30^{\circ} \mathrm{S}$ for lower winds, respectively.

\section{Comparison with sonde observations}

Before analyzing wind fields derived from cloud winds, we compare cloud winds with upper-air sonde observations to clarify the representativeness of cloud winds. We use 5 stations listed in Table 1 for comparison. Monthly mean $u$ (east-west) and $v$ (north-south) wind components for each station are compared with those derived from cloud winds at nearby grids points.
Table 1 Locations of upper-air observation stations used for comparison with cloud winds.

\begin{tabular}{lcc}
\hline STATION & LATITUDE & LONGITUDE \\
WAKE & $19^{\circ} \mathrm{N}$ & $167^{\circ} \mathrm{E}$ \\
KOROR & $7^{\circ} \mathrm{N}$ & $134^{\circ} \mathrm{E}$ \\
MAJURO & $7^{\circ} \mathrm{N}$ & $171^{\circ} \mathrm{E}$ \\
SINGAPORE & $1^{\circ} \mathrm{N}$ & $104^{\circ} \mathrm{E}$ \\
HONIARA & $9^{\circ} \mathrm{S}$ & $160^{\circ} \mathrm{E}$ \\
\hline
\end{tabular}

Original simple averaged cloud winds within $5^{\circ} \times 5^{\circ}$ boxes are used for comparison.

Fig. 2 shows time variations of $u$ and $v$ for upper cloud winds and those at $200 \mathrm{mb}$ and 150 $\mathrm{mb}$ by sonde observations at $\mathrm{KOROR}\left(7^{\circ} \mathrm{N}\right.$, $134^{\circ} \mathrm{E}$ ). Histograms of differences for upper winds from 200-mb, 150-mb and 100-mb sonde winds are shown in Fig. 3. Correlation coefficients between cloud winds and sonde winds are also listed in Fig. 3. The results in Figs. 2 and 3 reveal good correspondence of upper
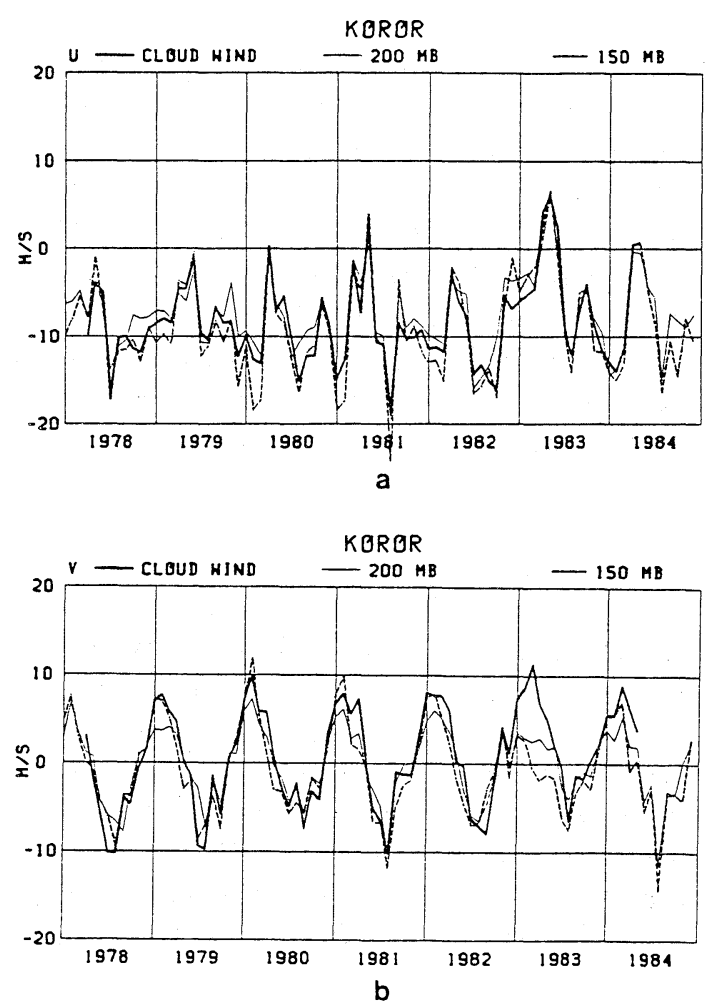

Fig. 2. Time variations of upper cloud winds (thick solid) and upper-air sonde $200-\mathrm{mb}$ (thin solid) and $150-\mathrm{mb}$ (dashed) winds at $\operatorname{KOROR}\left(7^{\circ} \mathrm{N}, 134^{\circ} \mathrm{E}\right)$. (a) $u$-components, (b) $v$-components. 


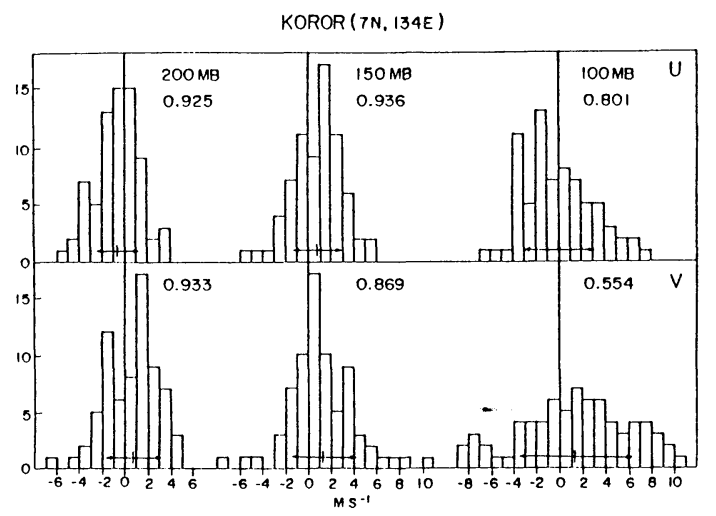

Fig. 3. Histograms of wind differences between upper cloud winds and sonde $200-\mathrm{mb}, 150-\mathrm{mb}$ and $100-\mathrm{mb}$ winds at $\operatorname{KOROR}\left(7^{\circ} \mathrm{N}, 134^{\circ} \mathrm{E}\right)$. Correlation coefficients are listed.

cloud winds to sonde 200-mb or $150-\mathrm{mb}$ winds except for $v$-components during early 1983. Correlation coefficients between these two winds are as high as about 0.9 and standard deviations of wind differences are about 2-3 $\mathrm{m} \mathrm{s}^{-1}$ (Fig. 3 ). Southerlies by the cloud winds seem to be overestimated during early 1983 when the cloud distributions and large-scale circulations in the entire Pacific region were largely affected by the 1982-83 El Niño event. Similar gaps of the $v$ components are also found at MAJURO $\left(7^{\circ} \mathrm{N}\right.$, $171^{\circ} \mathrm{E}$ ) (not shown). Probably these gaps between cloud-tracking winds and sonde winds may occur under abnormally perturbed conditions, but exact reasons for these differences are not clear.

Comparative results for lower winds with 850-mb, 700-mb and 500-mb sonde winds are shown in Figs. 4 and 5. Lower cloud winds correlate most with sonde $850-\mathrm{mb}$ winds and standard deviations of the difference between two are about $2 \mathrm{~m} \mathrm{~s}^{-1}$ for $u$-components and about $1 \mathrm{~m} \mathrm{~s}^{-1}$ for $v$-components, respectively. Westerlies during northern summer at KOROR derived from cloud winds are systematically smaller than sonde winds as shown in Fig. 4. However, systematic decreases of westerlies only occur for KOROR and may not affect the large-scale flow patterns over the whole analysis domain.

Similar comparison was made for other stations. Correlation coefficients between cloud winds and sonde winds and standard deviations
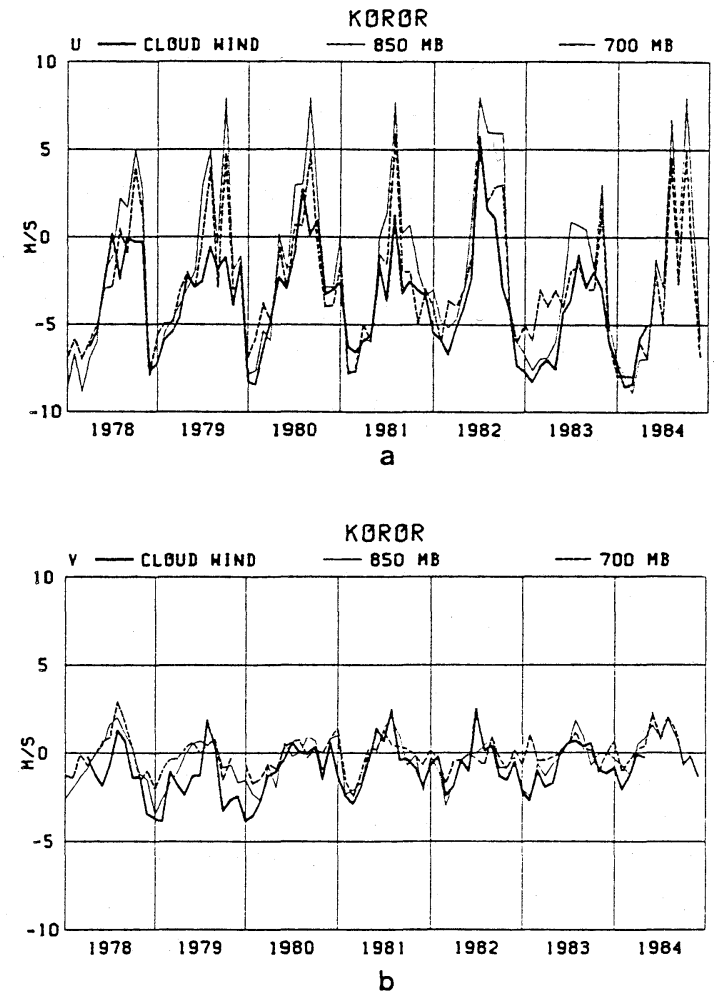

Fig. 4. As in Fig. 2 but for lower cloud winds and $850-\mathrm{mb}$ and $700-\mathrm{mb}$ winds at KOROR.

$\operatorname{KOROR}(7 N, 134 E)$

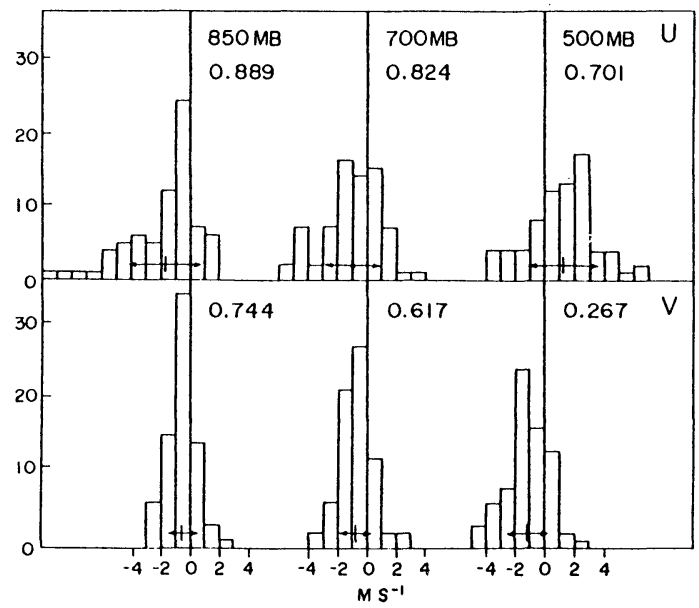

Fig. 5. Histograms of wind differences between lower cloud winds and sonde $850-\mathrm{mb}, 700-\mathrm{mb}$ and $500-\mathrm{mb}$ winds at KOROR. Correlation coefficients are listed. 
for both winds at 5 stations are listed in Table 2. It can be concluded from correlation results that upper cloud winds represent fairly well $200-\mathrm{mb}$ winds and that lower cloud winds represent $850-\mathrm{mb}$ winds. Correlation coefficients for lower winds are generally smaller than upper winds especially for $v$-components. These low values of correlation may be due to smaller amplitudes of wind variations in the lower troposphere than in the upper troposphere.

Standard deviations of $u$ for upper cloud winds are generally comparable to those for sonde winds at $200 \mathrm{mb}$, but $v$-components of upper cloud winds exhibit larger standard deviations than sonde winds. It appears that cloud tracking winds at high levels are liable to overestimate wind speeds in meridional direciton. For lower cloud winds $v$-components show slightly larger magnitudes of standard deviations than those for sonde winds at $850 \mathrm{mb}$, but $u$ components have smaller deviations than for sonde winds except for WAKE. Reasons for these systematic differences of standard deviations of lower cloud winds are not certain now but should be clarified in future.

Comparison results using monthly mean winds obtained in this study are generally consistent with those obtained by using instantaneous cloud wind observations by Hamada (1982). Hamada (1982) showed that high-level satellite winds over the tropical region agree with radiosonde winds at $200 \mathrm{mb}$ throughout the year but those over extratropical regions correspond to radiosonde winds at $250 \mathrm{mb}$ in summer, at $400 \mathrm{mb}$ in winter and at $300 \mathrm{mb}$ in spring and fall. By considering his results, montly mean upper winds in the extratropical region derived from GMS may correspond to winds at slightly lower levels than $200 \mathrm{mb}$, though comparison was not made in this study.

The representativeness of monthly mean cloud winds may also depend on data number used for averaging. Within a month period shortperiod variations due to synoptic or meso-scale systems exist and if averaging data numbers are small, these short-period variations are not smoothed out and the averaged winds may be biased. Fig. 6 shows the scatter diagrams of

Table 2 (a) Correlation coefficients between upper cloud winds $\left(u_{c}, v_{c}\right)$ and sonde winds $\left(u_{s}, v_{s}\right)$ at $200 \mathrm{mb}, 150 \mathrm{mb}$ and $100 \mathrm{mb}$ (COR) and standard deviations of both winds ( 6$)$ in units of $\mathrm{m} \mathrm{s}^{-1}$ for 5 stations.

\begin{tabular}{|c|c|c|c|c|c|c|c|}
\hline \multirow{2}{*}{ Station } & \multirow{2}{*}{$\begin{array}{l}\text { Sonde level } \\
\mathrm{mb}\end{array}$} & \multicolumn{3}{|c|}{$\mathrm{U}$} & \multicolumn{3}{|c|}{ V } \\
\hline & & $\mathrm{COR}$ & $\sigma\left(u_{c}\right)$ & $\sigma\left(u_{s}\right)$ & $\mathrm{COR}$ & $\sigma\left(v_{c}\right)$ & $\sigma\left(v_{S}\right)$ \\
\hline \multirow[t]{3}{*}{ WAKE } & 200 & 0.783 & 9.2 & 8.5 & 0.691 & 5.9 & 3.3 \\
\hline & 150 & 0.769 & - & 8.6 & 0.681 & - & 3.3 \\
\hline & 100 & 0.759 & - & 6.7 & 0.514 & - & 1.8 \\
\hline \multirow[t]{3}{*}{ KOROR } & 200 & 0.925 & 5.1 & 4.5 & 0.933 & 5.6 & 3.9 \\
\hline & 150 & 0.936 & - & 6.0 & 0.869 & - & 5.0 \\
\hline & 100 & 0.801 & - & 4.4 & 0.554 & - & 2.1 \\
\hline \multirow[t]{3}{*}{ MAJURO } & 200 & 0.945 & 6.6 & 5.2 & 0.827 & 4.2 & 2.4 \\
\hline & 150 & 0.915 & - & 6.4 & 0.615 & - & 2.0 \\
\hline & 100 & 0.794 & - & 5.9 & -0.159 & - & 1.3 \\
\hline \multirow[t]{3}{*}{ SINGAPORE } & 200 & 0.872 & 4.3 & 4.8 & 0.951 & 7.8 & 4.9 \\
\hline & 150 & 0.800 & - & 7.2 & 0.908 & - & 5.4 \\
\hline & 100 & 0.287 & - & 3.9 & 0.391 & - & 1.3 \\
\hline \multirow[t]{3}{*}{ HONIARA } & 200 & 0.833 & 5.5 & 4.4 & 0.810 & 3.8 & 3.3 \\
\hline & 150 & 0.852 & - & 5.1 & 0.729 & - & 3.4 \\
\hline & 100 & 0.711 & - & 5.3 & 0.285 & - & 3.7 \\
\hline
\end{tabular}


Table 2 (b) As in (a) but for lower winds. Results for SINGAPORE are not shown because of few lower cloud wind data near the station.

\begin{tabular}{|c|c|c|c|c|c|c|c|}
\hline \multirow{2}{*}{ Station } & \multirow{2}{*}{$\begin{array}{c}\text { Sonde level } \\
\mathrm{mb}\end{array}$} & \multicolumn{3}{|c|}{$\mathrm{U}$} & \multicolumn{3}{|c|}{ V } \\
\hline & & $\mathrm{COR}$ & $\sigma\left(u_{c}\right)$ & $\sigma\left(u_{S}\right)$ & COR & $\sigma\left(v_{C}\right)$ & $\sigma\left(v_{S}\right)$ \\
\hline \multirow[t]{3}{*}{ WAKE } & 850 & 0.886 & 2.8 & 2.7 & 0.547 & 1.4 & 1.0 \\
\hline & 700 & 0.811 & - & 3.9 & 0.453 & - & 1.0 \\
\hline & 500 & 0.749 & - & 5.8 & 0.436 & - & 1.3 \\
\hline \multirow[t]{3}{*}{ KOROR } & 850 & 0.889 & 3.0 & 4.6 & 0.744 & 1.4 & 1.2 \\
\hline & 700 & 0.824 & - & 3.4 & 0.617 & - & 0.9 \\
\hline & 500 & 0.701 & - & 2.9 & 0.267 & - & 0.7 \\
\hline \multirow[t]{3}{*}{ MAJURO } & 850 & 0.781 & 2.3 & 2.8 & 0.600 & 1.2 & 1.1 \\
\hline & 700 & 0.450 & - & 2.3 & 0.361 & - & 0.6 \\
\hline & 500 & 0.339 & - & 3.0 & 0.405 & - & 1.0 \\
\hline \multirow[t]{3}{*}{ HONIARA } & 850 & 0.852 & 2.3 & 3.2 & 0.275 & 1.4 & 1.2 \\
\hline & 700 & 0.862 & - & 2.7 & -0.006 & - & 0.8 \\
\hline & 500 & 0.749 & - & 2.2 & 0.186 & - & 1.0 \\
\hline
\end{tabular}

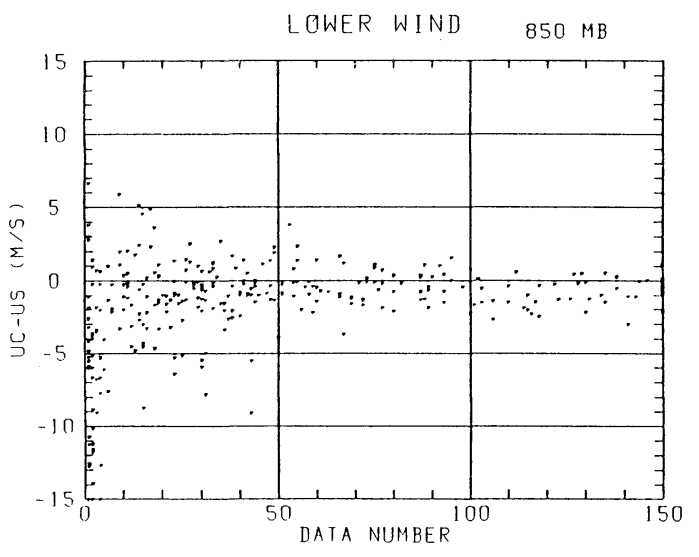

a

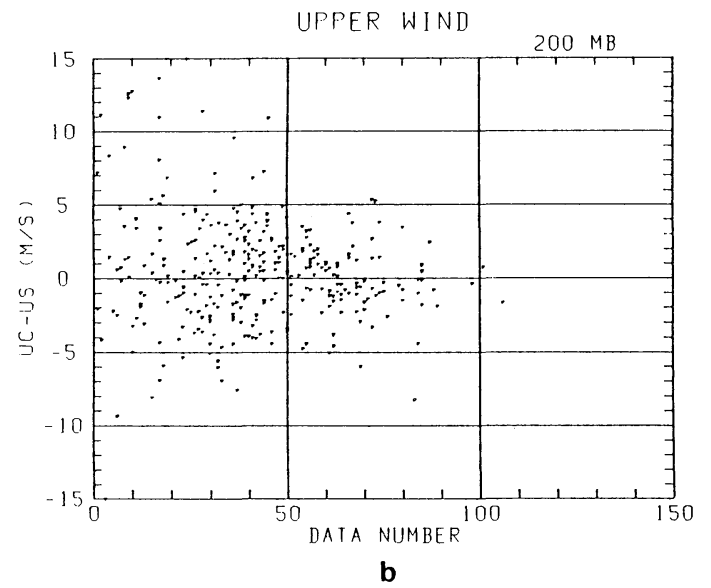

$u$-wind differences between lower cloud winds and $850-\mathrm{mb}$ winds and those between upper cloud winds and 200-mb winds as functions of the data density obtained by using all 5 stations. The $u$-components of lower cloud winds for the data number more than 50 are fairly close to $850-\mathrm{mb}$ winds within $\pm 1-2 \mathrm{~m} \mathrm{~s}^{-1}$. The wind differences become scattered as the data number decreases, but still most wind differences are within $\pm 2-3 \mathrm{~m} \mathrm{~s}^{-1}$ except for those with data number less than 10 . Since the data density for lower cloud winds is very localized as shown in Fig. 1(b), the lower winds are only analyzed in the limited region of $30^{\circ} \mathrm{N}-30^{\circ} \mathrm{S}$ and $125^{\circ} \mathrm{E}-$ $175^{\circ} \mathrm{W}$ where most of grids have higher. data density than 10 .

The wind differences for the upper cloud winds are scattered more than for the lower winds, probably due to larger wind speed at the upper levels. Most of the differences are within the ranges of $\pm 5 \mathrm{~m} \mathrm{~s}^{-1}$ except for the cases less than 10 or 20 data number. Since most of the regions have larger data density than $20 /\left(5^{\circ} \times\right.$

Fig. 6. Scatter diagrams (a) between lower cloud $u$ winds and $850-\mathrm{mb}$ sonde $u$-winds and (b) between upper cloud $u$-winds and 200 -mb sonde $u$-winds as functions of data number used for obtaining monthly mean cloud winds. 
$5^{\circ}$ )/month for the upper winds as shown in Fig. 1(a), upper winds in the domain of $45^{\circ} \mathrm{N}-45^{\circ} \mathrm{S}$ and $95^{\circ} \mathrm{E}-175^{\circ} \mathrm{W}$ are used for analysis.

Basing on the comparative results we conclude that monthly mean upper and lower winds derived from GMS cloud winds in the tropical regions represent quite well $200-\mathrm{mb}$ winds and $850-\mathrm{mb}$ winds within the ranges of $\pm 5 \mathrm{~m} \mathrm{~s}^{-1}$ and $\pm 2 \mathrm{~m} \mathrm{~s}^{-1}$, respectively and can be used for the analysis of long-term variations of tropospheric circulations in the tropical western Pacific regions. Caution, however, should be paid to the lower winds over the Australia where no cloud wind data are reported and interpolations from surrounding data are made. Also it should be reminded that upper-level meridional winds obtained by clouds seem to be overestimated.

\section{Mean seasonal variations}

Mean seasonal variations of large-scale flows in the western Pacific are examined based on 6 year averages of upper and lower winds for each month. Fig. 7 shows 6 -year averaged wind fields

\section{MEAN JAN}

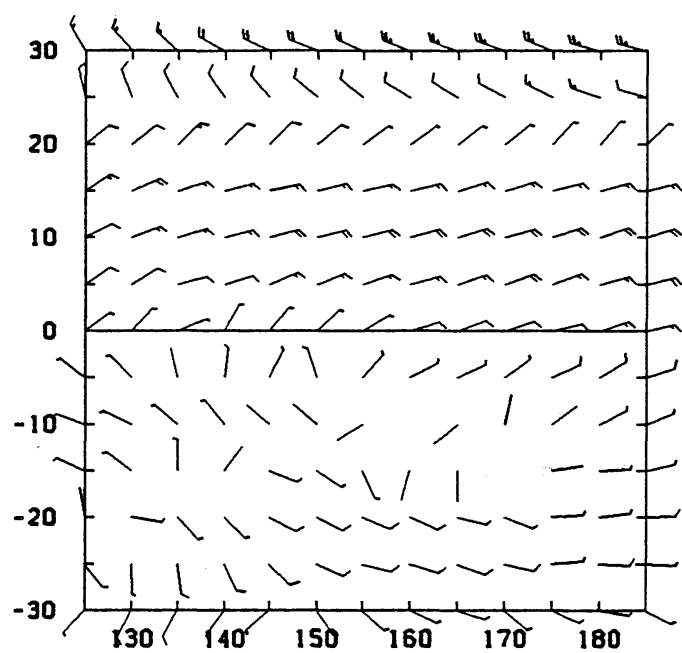

MEAN JUL

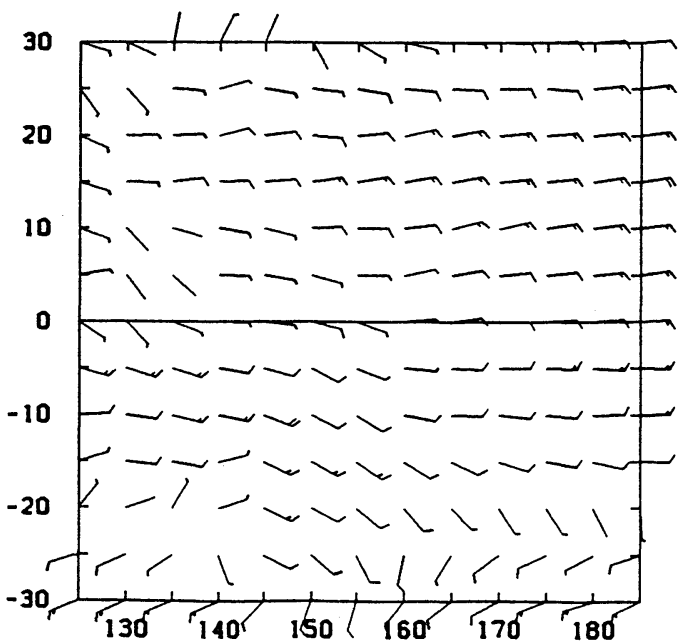

MEAN APR

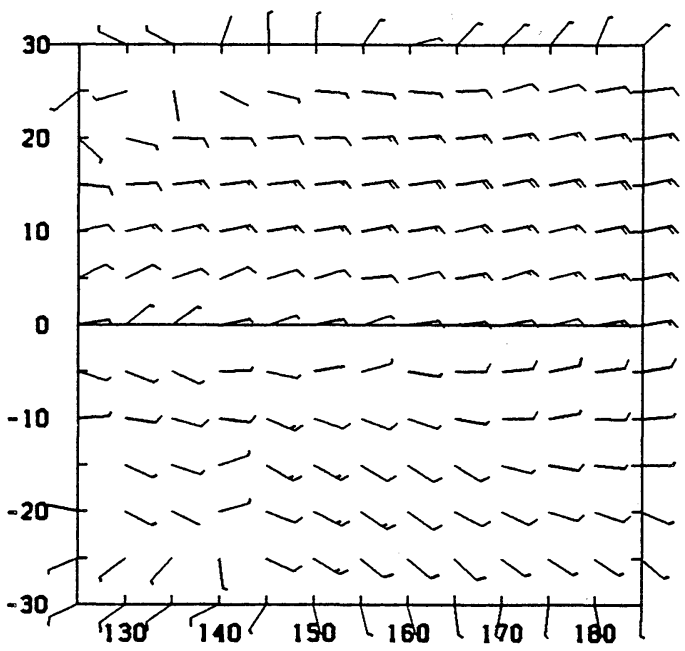

MEAN OCT

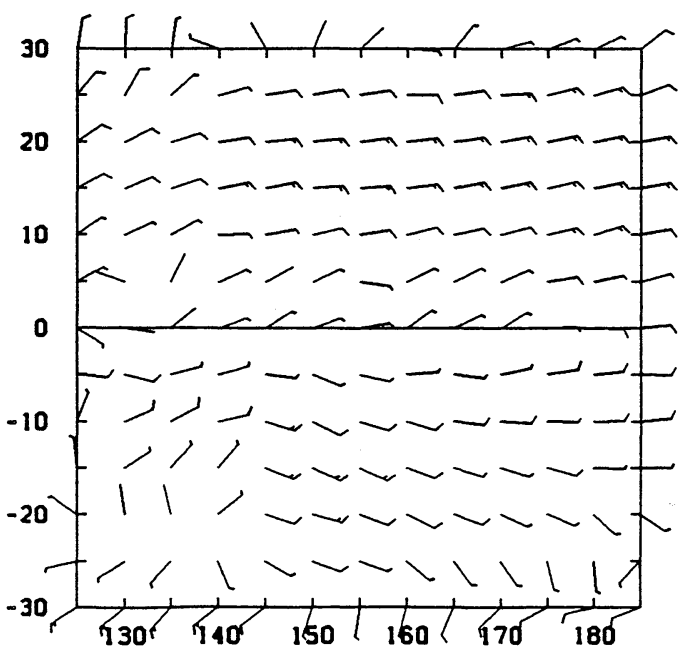

Fig. 7(a) 6-year averaged winds in January, April, July and October at lower levels. 
MEAN JAN

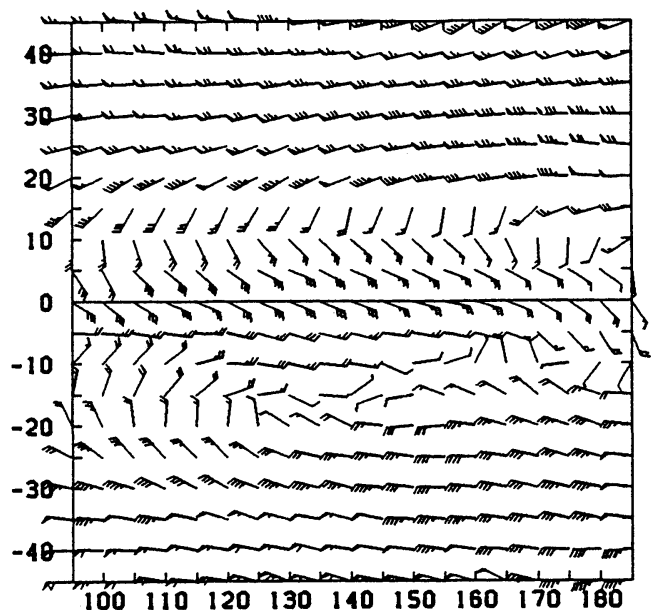

MEAN JUL

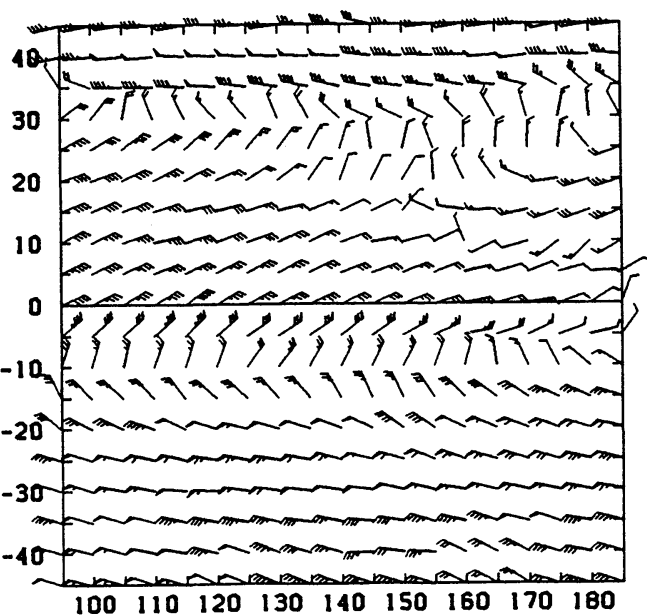

MEAN APR

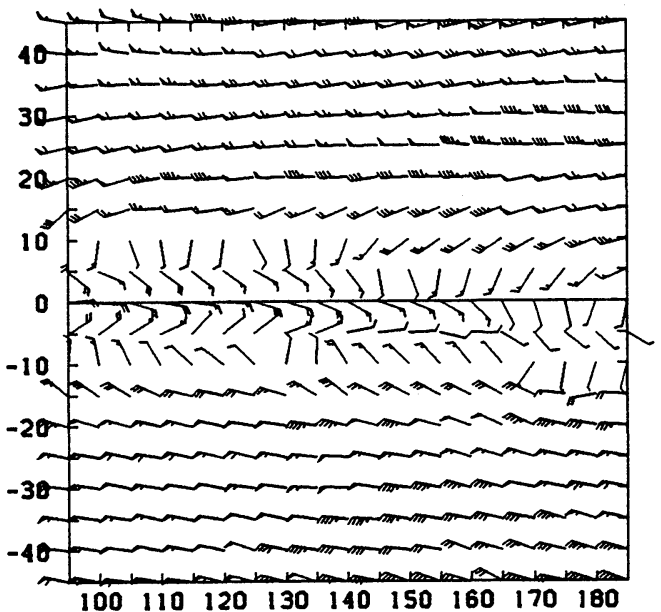

MEAN OCT

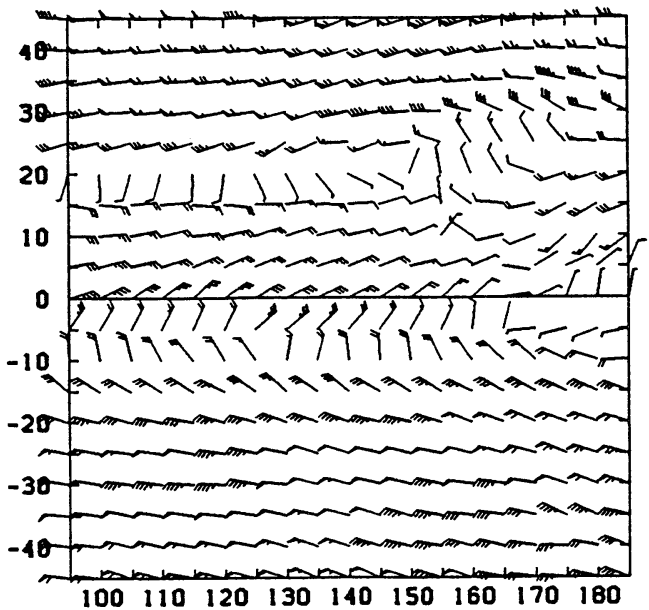

Fig. 7(b) As in Fig. 7(a) but for upper levels.

at lower and upper levels for January, April, July and October. In January prevailing northerly winds from the Asian Continent turn their direction from northwesterly to northeasterly in the lower troposphere near $25^{\circ} \mathrm{N}$ and extend into the Southern Hemisphere ( $\mathrm{SH}$ ) crossing the equator. Northwesterlies in the $\mathrm{SH}$ equatorial region south of maritime continent converge into the Australian monsoon region. In the upper troposphere an intense anticyclonic circulation is stationed over the North Australia and southeasterlies outflow from the anticyclonic center to the Northern Hemisphere. Mid- latitude westerlies in $\mathrm{NH}$ extend into the equatorial region near $15^{\circ} \mathrm{N}$.

In April the wind fields in the lower and upper troposphere are generally symmetric with respect to the equator corresponding to nearly symmetric heat source distributions around the equator as analyzed by N. Nearly zonal easterlies prevail in the lower tropospheric equatorial region. Upper easterlies are limited in the narrow equatorial region between $5^{\circ} \mathrm{N}$ and $5^{\circ} \mathrm{S}$ and anticyclonic circulations are found both north and south of these easterlies.

In July easterly regions in the $\mathrm{NH}$ lower 
troposphere extend northward to middle latitudes. In the upper troposphere an anticyclonic circulation associated with the Tibetan High becomes dominant and northeasterlies situated to the southeast of the Tibetan High are intensified in the equatorial western Pacific, while the Mid-Pacific Trough (MPT) deepens near the dateline. MPT appears first in May over the tropical western Pacific region near $140^{\circ} \mathrm{E}$ (not shown) and shift eastward to around the dataline with increasing its amplitudes during the $\mathrm{NH}$ summer. In October lower southeasterlies to the west of about $140^{\circ} \mathrm{E}$ change to northeasterlies. Tibetan High in the upper troposphere is weakened and a weak anticyclonic cell stays in the western Pacific around $20^{\circ} \mathrm{N}$. MPT continues to exist till about October.

These seasonal features of large-scale wind fields over the western Pacific region correspond to seasonal distributions of heat sources as analyzed by $\mathrm{N}$ and are largely controlled by the Southeast Asian and the Australian monsoons. The season mean circulation patterns obtained in this study are generally similar to earlier results by Krishnamurti (1971) and recent results during the FGGE year (ex. Bengtsson et al., 1982). However, lower westerlies found to the north of Australia in $\mathrm{NH}$ winter seem to be weak as compared to the FGGE results and the cloud winds may be underestimated for the lower westerlies during the Australian monsoon period. The data number $(10-20)$ in these regions used for analysis may not be sufficient to smooth the short-period variations.

\section{EOF analysis of non-seasonal wind variations}

In addition to regular seasonal variations as described in the previous section, there might exist non-regular wind variations such as interannual and intraseasonal variations. Both seasonal and non-seasonal variations can be seen in the time-longitude sections of $u$ at the lower and upper levels along the equator as shown in Fig. 8. In the lower troposphere the strength of easterlies in the eastern part of the analyzed area increases both in the $\mathrm{NH}$ summer and winter corresponding to summer and winter monsoon activities, while westerlies are found in the western part during the $\mathrm{NH}$ winter corresponding to the Australian monsoon. In the upper troposphere easterlies dominate over the western Pacific and their intensities are strenth-
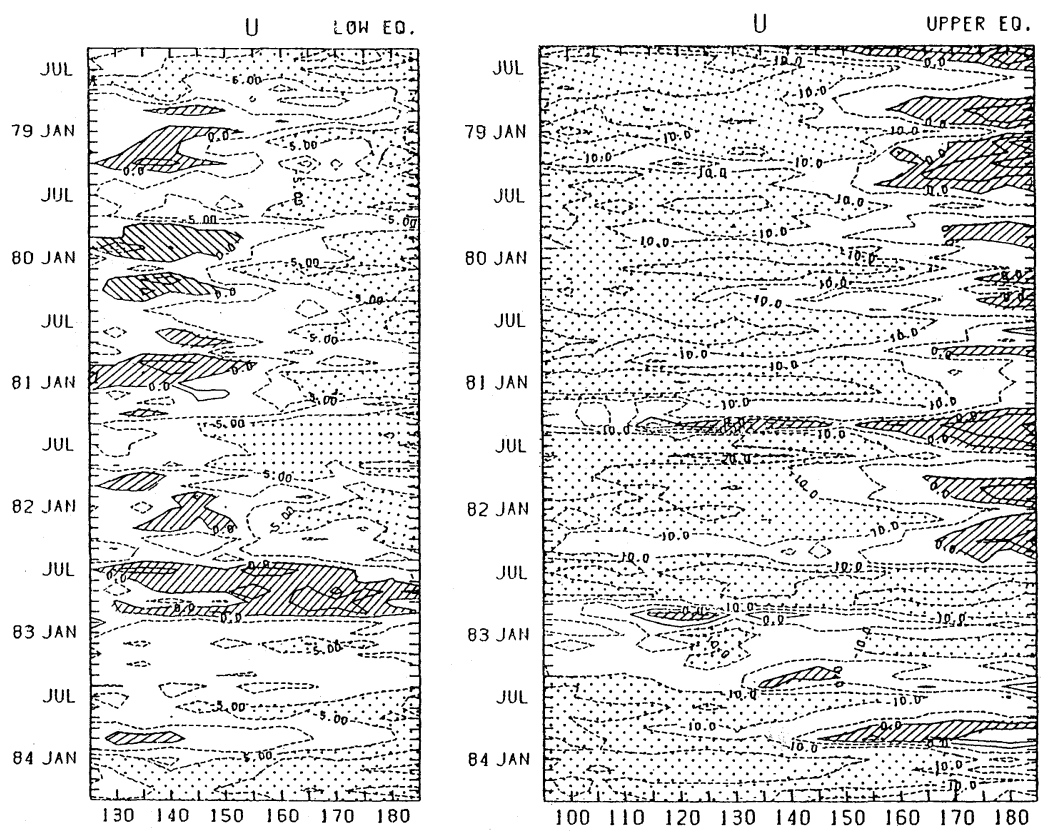

Fig. 8. Time-longitude sections of zonal winds at the equator for lower levels (left) and upper levels (right). Westerly regions are stripped and strong easterly regions are shaded. 
ened during summer and winter seasons. Westerlies appear in the central Pacific during spring and fall seasons.

Appearance and persistency of lower westerlies and upper strong easterlies over the whole western Pacific during late 1982 are the largest nonregular variations within the analyzed period. These large wind anomalies are due to the 1982-83 El Niño event. Westerlies in the lower troposphere suddenly appear in the western Pacific in July and at almost the same time upper easterlies are intensified corresponding to the onset and development of the El Niño. Both lower westerlies and upper easterlies extend further eastward to the central Pacific and possibly to the eastern Pacific during late 1982. Detailed wind anomaly patterns associated with the 1982-83 El Niño will be discussed in Section 6.1 .

In contrast to weak easterlies in lower levels during the El Niño winter (1982-83), easterlies are strentghened during the 1983-84 winter probably corresponding to the phase of $\mathrm{La}$ Niña.

The results as shown in Fig. 8 indicate that actual wind fields possess various types of nonseasonal variations. $\mathrm{N}$ analyzed long-term variations of the cloud amount in the same region as in this study and found two types of dominant non-seasonal variation patterns of tropical heat source anomalies, i.e., one is the $\mathrm{EN}$ (El Niño) pattern and the other is the PJ (western Pacific - Japan) pattern. One-point correlation maps of cloud amount corresponding to the EN and $\mathrm{PJ}$ patterns obtained by $\mathrm{N}$ are shown in Fig. 9 . The EN pattern consists of an east-west oscillation of cloud amount between the western Pacific and the central Pacific along the equator and was extensively amplified during the 198283 El Niño period. The PJ pattern consists of a north-south oscillation between the western Pacific subtropics and middle latitudes around Japan and becomes dominant during $\mathrm{NH}$ summer. Large-scale atmospheric circulations may respond to these heat source anomalies. In this section characteristic features of non-seasonal wind variations are examined by the use of EOF analysis and the relationships between the heat source and wind anomalies for EN and PJ will be detailed in the next section.

Before performing EOF analysis we eliminate regular seasonal variations such as annual and semiannual variations by subtracting the 6-year averaged values from original wind data for each month. Since upper and lower winds in the tropics generally vary in a coupled manner with
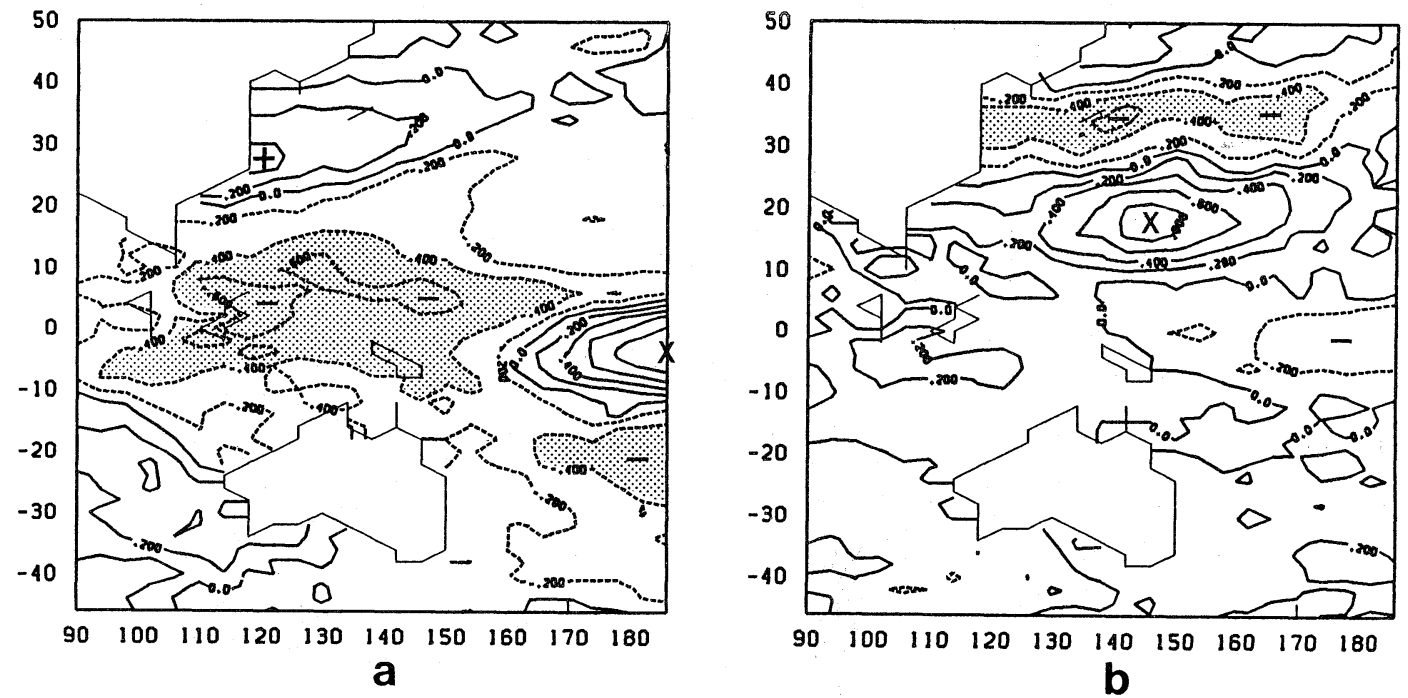

Fig. 9. One-point correlation maps by taking reference points (a) at $4^{\circ} \mathrm{S}, 174^{\circ} \mathrm{W}$ and (b) at $18^{\circ} \mathrm{N}, 146^{\circ} \mathrm{E}$ obtained by N. Solid and dashed lines denote positive and negative correlations, respectively. Contour interval is 0.2 and regions with negative correlation coefficients smaller than 0.4 are shaded. 
each other, EOF analysis is applied together to zonal and meridional winds at both levels for 72 months. Upper winds at $5^{\circ}$ (latitude) $\times 10^{\circ}$ (longitude) grids are used to reduce the dimension of covariance matrix for the EOF analysis.

Fig. 10 shows the wind fields at upper and lower levels for the first eigenvector which accounts for about $13 \%$ of the total variance. Time variations of the coefficient of this eigenvector are shown in Fig. 11 together with those for the first eigenvector of the cloud amount corresponding to the EN mode obtained by $\mathrm{N}$. Fig. 11 shows that the first eigenvector of winds is extremely amplified during the period from mid-1982 to mid-1983 corresponding to the 1982-83 El Niño and therefore it can be concluded that wind anomalies for the first eigenvector are largely due to the El Niño event. At lower levels westerly anomalies are found near the equator to the east of about $150^{\circ} \mathrm{E}$ and easterly anomalies exist to the west. An anticyclonic circulation appears in the $\mathrm{NH}$ subtropics but a cyclonic circulation exists in the SH subtropics. At upper levels southeasterlies in the $\mathrm{NH}$ equatorial region and northeasterlies in the $\mathrm{SH}$ equatorial region to the east of $150^{\circ} \mathrm{E}$ turn to the west direction in the subtropics producing anticylonic circulations in both hemispheres. Westerlies are dominant in the equatorial region to the west of $150^{\circ} \mathrm{E}$ and cyclonic circulation anomalies are found in East China Continent and over the Australia. Upper-level convergence and lower-level diver- gence seem to occur in the equatorial western Pacific centered around $150^{\circ} \mathrm{E}$. These wind anomaly fields are generally consistent with those obtained during the mature phase of the 1982-83 El Niño (ex. Quiroz, 1983).

Fig. 11 also indicates that time variations of the first mode of winds correlate quite well with those of cloud amount corresponding to the cloud EN mode as obtained by $\mathrm{N}$. The correlation coefficient between two is as high as 0.85 . Both amplitudes increase rapidly after the onset of El Niño in 1982 and becomes peaked during 1982-83 winter corresponding to the mature phase of the El Niño. It is interesting to note that both variations correlate quite well not only during the 1982-83 El Niño period but also during the non-El Niño periods in which intraseasonal variations with a few month time-scale dominate. These results suggest that large-scale atmospheric circulations coupled with east-west heat source anomalies as shown in Fig. 9(a) exist with intraseasonal time-scales during non-El Niño periods but amplify significantly during the El Niño event. Relationships between tropical intraseasonal variations and ENSO have been also discussed by Lau and Chan $(1985,1986)$ in terms of tropical convective activities.

The results for the second eigenvector which accounts for about $6 \%$ of the total variance (not shown) suggest that this mode seems to correspond to the PJ heat source anomaly as shown in Fig. 9(b). However the wind fields
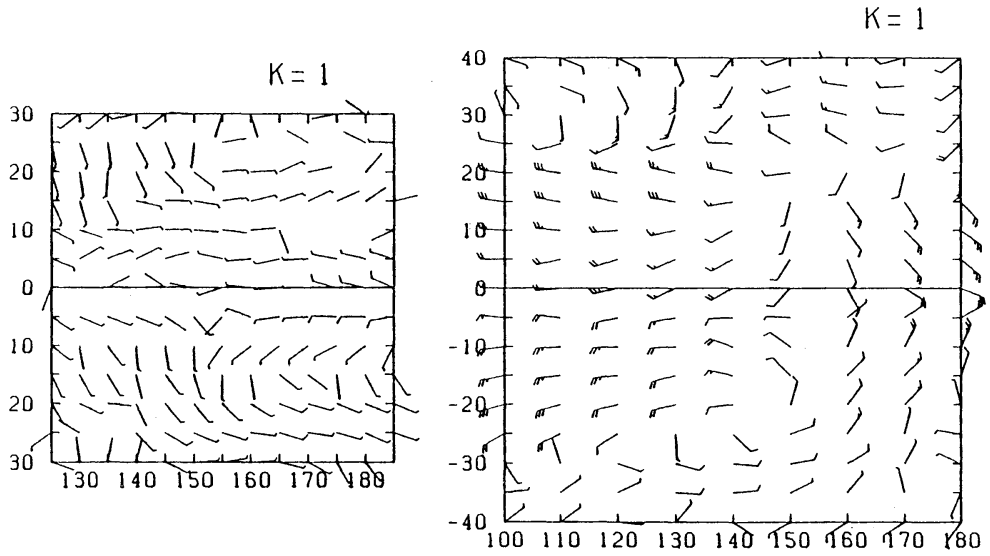

Fig. 10. Wind fields for the first eigenvector at lower (left) and upper (right) levels. 


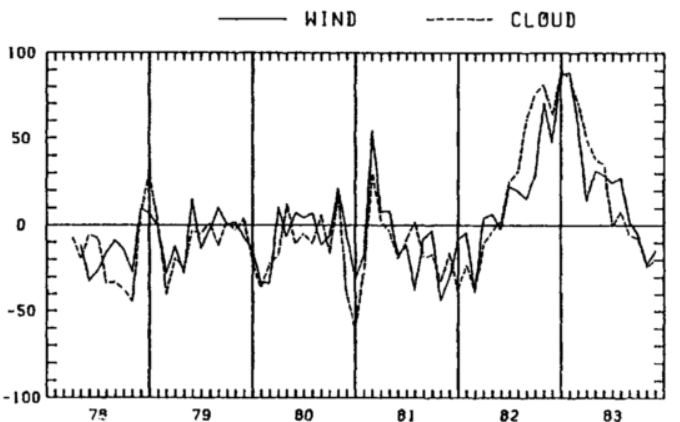

Fig. 11. Time variations of the coefficient for the first eigenvector of winds (solid) and those of cloud amount (dashed). Units are arbitrary.

for the second eigenvector and composite wind anomaly fields for $\mathrm{PJ}$ as will be shown in 6.2 are slightly different form each other. Since the cloud PJ oscillation is mostly dominant during $\mathrm{NH}$ summer, we recompute eigenvectors by using wind data during summer seasons only (June-August) to obtain wind fields associated with PJ. Fig. 12 shows the wind fields for the first eigenvector and its coefficients obtained from 6 summers data (18 months). This eigenvector accounts for about $25 \%$ of the total variance. The PJ index of the cloud amount defined by $\mathrm{N}$ is also plotted in the figure. Time variations of this wind eigenvector correlate quite well with the $\mathrm{PJ}$ index with the correlation coefficient of about 0.9 . Wind fields for this mode are almost the same as those obtained by composite analysis for PJ (Fig. 15). It can be concluded that the first eigenvector of winds obtained from summer data only corresponds to the PJ heat source anomaly. Detailed features of wind anomalies associated with $\mathrm{PJ}$ will be discussed in 6.2.

Other eigenvectors for the wind EOF analysis account for little contributions to the total variance and do not seem to be significant.

\section{Relationships between wind and tropical heat source anomalies}

\subsection{Wind anomaly patterns during the 1982- 83 El Niño period}

The EOF results in the previous section showed that both the first eigenvectors of winds and the cloud amount are intensified extremely during the 1982-83 El Niño. In order to ex- amine the relationship between wind fields and heat source patterns during the mature phase of the El Niño, anomaly patterns of upper winds and cloud amount averaged during November 1982 - March 1983 are shown in Fig. 13. As described in the previous section wind fields in Fig. 13 are almost the same as those obtained as the first eigenvector of the EOF analysis (Fig. $10)$. Large positive cloud anomaly is concentrated near the equator in the central Pacific and divergent flows are directed westward and poleward from the heat source region. The equatorial western Pacific is occupied by heat sink anomaly and westerly wind anomalies are prevailing in this region. Equatorial easterlies from the central Pacific and westerlies from the Indian Ocean converge near $150^{\circ} \mathrm{E}-160^{\circ} \mathrm{E}$ where maximum heat sinks occur. Lower winds (not shown), which are almost the same as Fig. 10, indicate the divergence near this region suggesting that there exists a descending center of the large-scale Walker circulation connecting to the eastern Pacific and Indian Ocean. It is interesting to note in Fig. 13 that a cyclonic circulation anomaly exists in the region extending from Southeast China to East China Sea where positive cloud amount anomalies* appear. Kodama** analyzed cloud amount variations over the Far East Asia during 1982 - 83 based on daily dataset and found that cloud amount variations to the south of Japan Islands during winter and spring of $1982-83$ are strongly related to passage of mid-latitude cyclones. These results suggest that the cyclonic circulation is intensified in East Asian storm track regions during the $\mathrm{El}$ Niño period and disturbance activities are enhanced in these regions resulting in positive cloud amount anomaly. These cyclonic circulation anomalies and enhanced precipitation over the Far East Asia are also found in the modelcomputed El Niño events by Lau (1985), but physical mechanism producing these anomalies is not clear and further studies are needed in future.

As presented in Fig. 8, lower westerlies suddenly appear on the equator in July of

\footnotetext{
*Cloud amount data are not available over continents and large islands.

**Personal communications.
} 

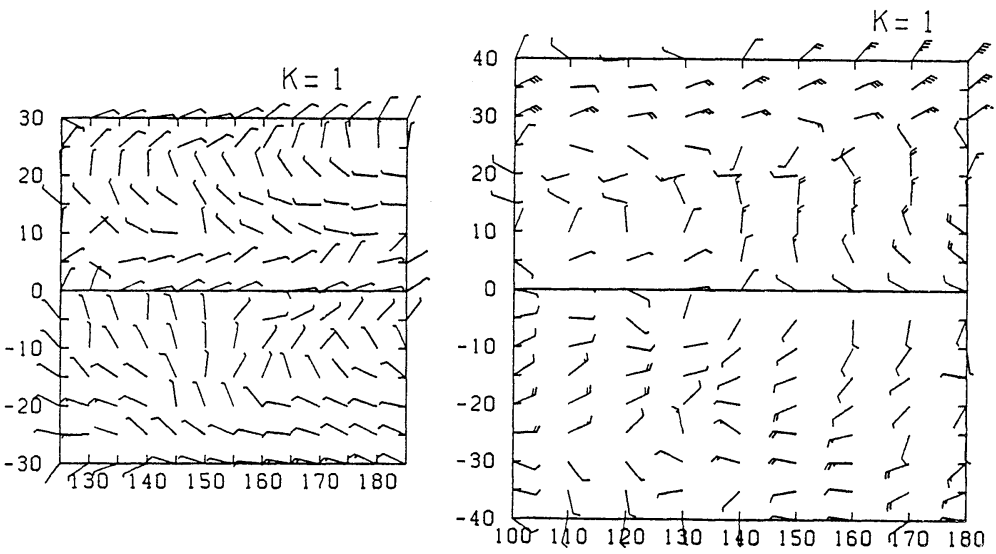

a

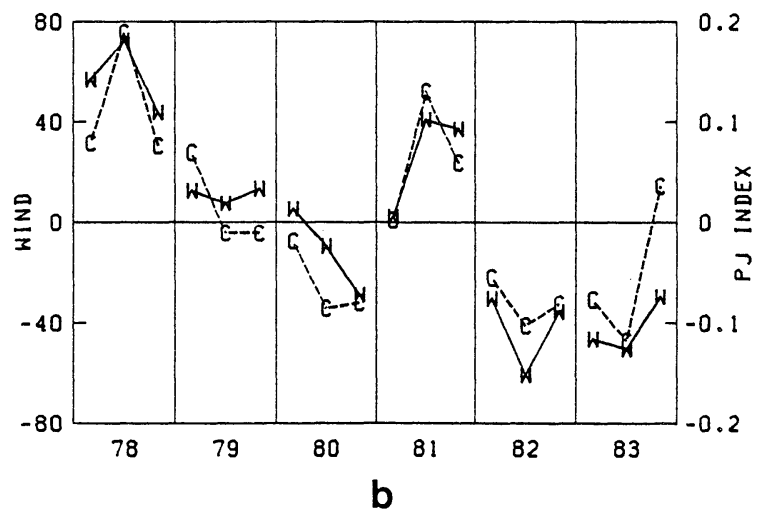

Fig. 12. (a) Wind fields for the first eigenvector at lower (left) and upper (right) levels obtained from summer data only and (b) its time coefficients (solid lines). The PJ index of the cloud amount is also plotted (dashed lines).

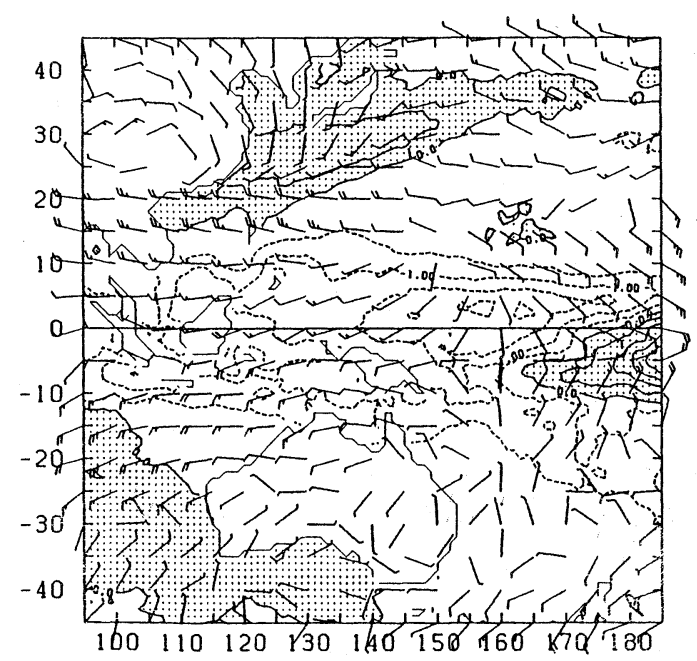

1982 corresponding to the onset of the El Niño. Low-level westerlies are thought to be important for the occurrence of the coupled ocean - atmosphere instability as demonstrated by Philander et al. (1984). Original cloud wind data near the equator are plotted to examine how suddenly lower westerly appears. Daily wind fields close to the equator from June to July in 1982 (not shown) indicate that the equatorial western Pacific region is mostly dominated by easterlies during the first half of June but that westerlies appear in late June to

Fig. 13. Wind anomalies at upper levels and cloud amount anomalies during the period from November 1982 to March 1983. Contour interval of the cloud amount is 0.5 and positive anomaly regions are shaded. 
the west of about $160^{\circ} \mathrm{E}$ and extend gradually eastward.

Fig. 14 plots low-level cloud wind data together with conventional upper-air observations at $850 \mathrm{mb}$ within 5 days before and after the appearance of equatorial westerlies. During the earlier period (24-28 June 1982) westerlies found in the $\mathrm{NH}$ tropical western Pacific seem to be limited to the west of about $140^{\circ} \mathrm{E}$, although exact border lines between westerlies and easterlies are hard to be drawn in $0^{\circ}-10^{\circ} \mathrm{N}$ latitudes to the west of $150^{\circ} \mathrm{E}$ where almost no cloud wind data are obtained probably due to the existence of active cloud clusters. For the latter period (29 June - 3 July 1982) equatorial westerlies envade far eastward into about $170^{\circ} \mathrm{E}$. Meridional extent of westerlies is as wide as about 10 degrees latitude at about $150^{\circ} \mathrm{E}$ but decreases as the region moves eastward. These results suggest that the burst of westerlies relat-

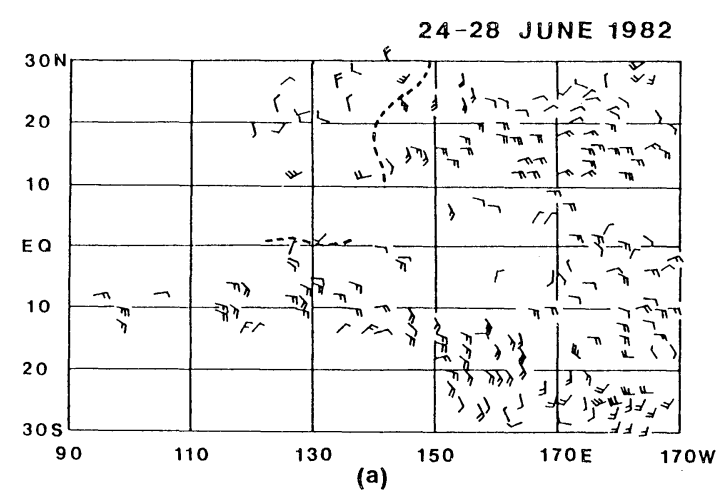

29 JUNE-3 JULY 1982

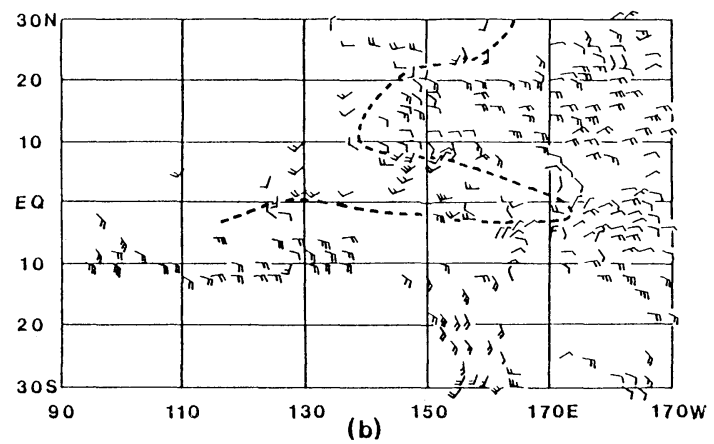

Fig. 14. Plots of winds at lower levels observed in (a) 24-28 June 1982 and (b) 29 June - 3 July 1982. Dashed lines denote border lines between westerlies and easterlies. ing to the onset of $1982 / 83 \mathrm{El}$ Niño appears to occur in the period from late June to early July. However, since low-level cloud wind data close to the equator were quite few during the latter half of June as shown in Fig. 14(a), the exact timing of the westerly burst is left to be inconclusive. Upper cloud wind and cloud amount data (not shown) indicate that cloud clusters to the north of New Guinea were developed in middle June and upper easterlies were intensified accordingly. Further detailed analysis of wind fields at both lower and upper levels together with convective activity is needed to clarify how lower and upper winds and convection were coupled with each other during the initial phases of the 1982/83 El Niño.

\subsection{Wind perturbations associated with the western Pacific - Japan heat source anomaly}

The results in the previous section showed that the first eigenvector of the EOF analysis obtained from summer data only corresponds to the PJ cloud variation. This cloud variation becomes noticeable during summer seasons and is closely related to the interannual variations of SST in the tropical western Pacific. When SST is above normal, convection centers shift northward by $5^{\circ}-10^{\circ}$ latitudes from the normal position and convective activities near Japan to the north of convection centers are suppressed.

Wind anomalies associated with the PJ cloud variation are composited by using three positive extremes and three negative extremes of the PJ cloud variations. Fig. 15 shows upper and lower wind fields obtained by subtracting mean negative extreme cases (August 1980, July 1982 and July 1983) from mean positive extreme cases (July 1978, August 1978 and July 1981). Positive cloud amount anomalies larger than $10 \%$ corresponding to these periods are also shown in the figure. The composite wind fields are almost the same as those for the first eigenvector obtained by summer data only as shown in Fig. 12. At lower levels a cyclonic circulation is found along the heat source center around $20^{\circ} \mathrm{N}$ and there is an indication of an anticyclonic circulation to the north of about $25^{\circ} \mathrm{N}$. At upper levels there exist outflows from the heat source region directed poleward and equato- 

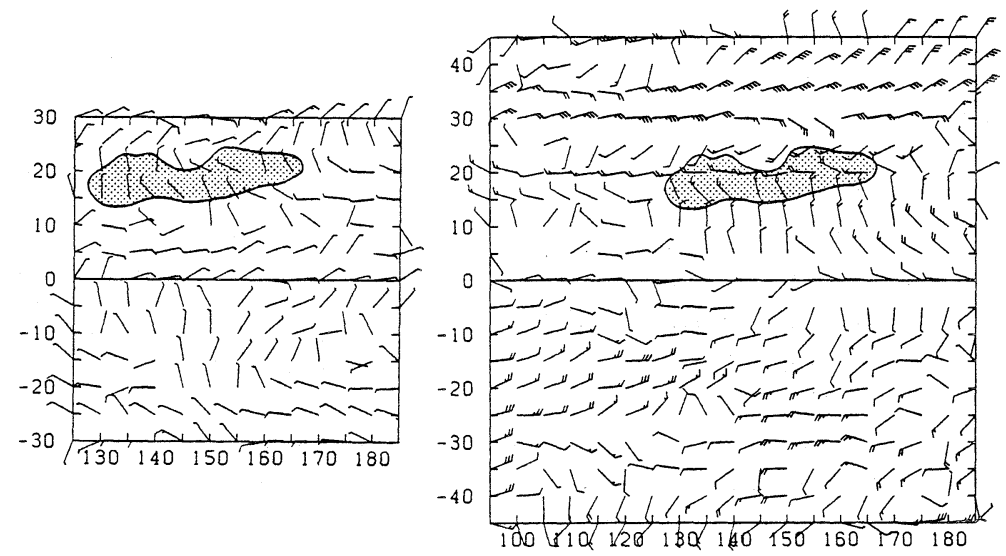

Fig. 15. Composited wind anomalies at lower levels (left) and upper levels (right) for the western Pacific-Japan cloud oscillation. Regions with cloud amount anomalies larger than 1.0 tenth are shaded.

ward and strong easterlies are found to the north of the heat source. A cyclonic cell with a center around $25^{\circ} \mathrm{N}$ is generated to the south of these easterlies and an anticyclonic cell with a center around $40^{\circ} \mathrm{N}$ exists to their north. This anticyclonic cell seems to extend from East China Continent to North Pacific crossing the Japan Islands. Appearance of the north-south dipole circulation may correspond to the northward shift of the subtropical high pressure area in the western Pacific. During both summers in 1978 and 1981 Japan was mostly covered by the dominant subtropical Pacific High and experienced hot summers, while during 1980, 1982 and 1983 Japan has suffered heavey rainfall (July in 1982 and 1983) and abnormal cool summer (August 1980). The anticyclonic cell generated in the middle latitudes seem to have barotropic nature, but its detailed vertical and horizontal structure cannot be resolved solely by GMS cloud wind data and further analysis using other data sources in the global Northern Hemisphere is needed to obtain large-scale circulation anomalies assocaited with the $\mathrm{PJ}$ heat source variation.

\section{Conclusions}

Cloud wind data derived from GMS are analyzed to study seasonal and non-seasonal variations of large-scale circulations in the western Pacific region. Comparison with conventional upper-air observations and analysis results indicate that satellite wind data can be used for the studies of long-term variations of tropical and subtropical circulations in high quality. Especially over the tropical oceanic areas where conventional upper-air data are very limited, satellite-derived wind data may provide valuable information regarding the interannual changes of atmospheric circulations such as associated with ENSO.

Comparative analyses show that monthly mean lower and upper winds obtained by GMS cloud-tracking fairly well represent $850-\mathrm{mb}$ and $200-\mathrm{mb}$ winds in the tropical regions, respectively. Accuracies of monthly mean cloud winds seem to be related to data densities and further operational efforts to get cloud wind vectors with high and uniform data density may be needed for obtaining more reliable climatic data.

EOF analyses of winds show that wind anomalies associated with the El Niño during 1982-83 are obtained as the first eigenvector. These wind anomalies suggest the existence of a large-scale east-west circulation along the equator with rising motion in the eastern Pacific and sinking motion in the western Pacific which are responding to equatorial heat source anomalies. Westerlies in the upper troposphere are intensified in the subtropics northwest of the sinking center $\left(\sim 150^{\circ} \mathrm{E}\right)$ and a cyclonic anomaly circulation is found to the north of westerlies. These anomaly wind fields in the upstream of the eastern Pacific heat source might give significant impact on winter climate in the Southeast Asia, 
but mechanism of generating these anomaly fields has not been explained and further observational and theoretical studies might be needed. Time variations of the amplitudes of the first mode for the winds correlate quite well with those for the cloud amount obtained by $\mathrm{N}$ not only during the 1982-83 El Niño period but for the non-El Niño periods indicating that atmospheric circulations respond very sensitively to the tropical heating.

Time-longitude sections of zonal winds at the equator reveal abrupt appearance of lowlevel westerlies and intensification of upperlevel easterlies in July 1982 corresponding to the onset of 1982-83 El Niño. Further detailed time evolution of winds, convective activities and ocean surface currents may be needed to delineate initiation processes of the El Niño.

Wind anomalies associated with the western Pacific - Japan cloud variation are obtained as the first eigenvector of the EOF analysis using summer data only and almost the same wind patterns are also derived from the composite analysis. When convective activities are enhanced in the western Pacific subtropics around $20^{\circ} \mathrm{N}$, a cyclonic circulation appears just to the northwest of the heat source center and an anticyclonic circulation is found to the north of $30^{\circ} \mathrm{N}$. These pairs of cyclonic and anticyclonic cells may correspond to northward shift of the subtropical high in the western Pacific due to the PJ heat source anomalies. Detailed time evolution of the PJ pattern and response of atmospheric large-scale motions are currently being analyzed by the use of more time-resolved cloud amount and global height data and the results will be reported soon.

\section{Acknowledgements}

The authors express their thanks to Japan Meteorological Satellite Center for providing cloud wind data. Computations for analyses were made by $\mathrm{M}-200 \mathrm{H}$ and $\mathrm{S}-810$ Computors in MRI.

\section{References}

Bengtsson, L., M. Kanamitsu, P. Kållberg and S. Uppala, 1982: FGGE research activities at ECMWF. Bull. Amer. Meteor, Soc., 63, 277-303.

Hamada, T., 1979: Cloud wind estimation system. Meteorological Satellite Center Tech. Note, Special issue II-2, 15-42 (in Japanese).

- 1 1982: Representative heights of GMS satellite winds. Meteorological Satellite Center Tech. Note, 6, 35-47.

___ and K. Kato, 1984: A new procedure of objective target cloud selection for the GMS cloud wind estimation system and the accuracy of the resultant wind vectors. Meteorological Satellite Center Tech. Note, 9, 27-83 (in Japanese).

Ichizawa, J., 1983: A history of the satellite wind estimation at MSC and the present accuracy of satellite winds. Meteorological Satellite Center Tech. Note, 8, 85-100 (in Japanese).

Kato, M., 1980: Comparison of satellite derived cloud wind and rawin-sonde data. Meteorological Satellite C'enter 'lech. Note, 2, 61-'/5 (in Japanese).

Krishnamurti, T.N., 1971: Observational study of the tropical upper tropospheric motion field during the Northern-Hemisphere summer. J. Appl. Meteor., 10, 1066-1096.

Lau, K.-M. and P.H. Chan, 1985: Aspects of the 40-50 day oscillation during the Northern winter as inferred from outgoing longwave radiation. Mon. Wea. Rev., 113, 1889-1909.

and - 1986: The 40-50 day oscillation and the E1 Niño Southern Oscillation: A new perspective. Bull. Amer. Meteor. Soc., 67, 533-534.

Lau, N.C., 1985: Modeling the seasonal dependence of the atmospheric response to observed E1 Niño in 1962-76. Mon. Wea. Rev., 113, 1970-1996.

Madden, R.A. and P.R. Julian, 1971: Detection of a 40-50 day oscillation in the zonal wind in the tropical Pacific. J. Atmos, Sci., 28, 702-708.

Nitta, Ts., 1986: Long-term variations of cloud amount in the western Pacific region. J. Meteor. Soc. Japan, 64, 373-390.

Philander, S.G.H., T. Yamagata and R.C. Pacanowski, 1984: Unstable air-sea interaction in the tropics. J. Atmos. Sci., 41, 604-613.

Quiroz, R.S., 1983: The climate of the "El Niño" winter of 1982-83 - A season of extraordinary climate anomalies. Mon. Wea. Rev., 111, 16851706.

Rasmusson, E.M. and T.H. Carpenter, 1982: Variations in tropical sea surface temperature and surface wind fields associated with the Southern Oscillation/El Niño. Mon. Wea. Rev., 110, 354-384. 


\title{
静止気象衛星による雲風データを用いた西部太平洋域の 循環場の長期変動の解析
}

\author{
新田就・丸 山 健 人 \\ (気 象 研 究 所) \\ 元 木 敏 博 \\ (気象衛星センター)
}

静止気象衛星による 6 年間（1978年～1984年）の雲風デー夕を用いて，西部太平洋域における大気循 環場の長期変動を調べた。ゾンデによる高層観測風との比較の結果, 衛星による月平均上層風は $200 \mathrm{mb}$ の風に，また，下層風は $850 \mathrm{mb}$ の風にほぼ対応することがわかった。

各月ごとに 6 年平均した風の解析から, 西太平洋域の風の場は, 夏, 冬のモンスーン循環の影響を大 きく受けていることがわかる。北半球の夏期, 上層の熱帯西部太平洋域は, 優勢なチベット高気圧の南 東にあたり，北東気流が卓越する。一方，冬期は，オーストラリア上空の高気圧からの南東流が卓越す る。

風の場の主成分解析を行った。第 1 主成分は，1982-83年のエルニーニョに伴う風の場を表わし，赤 道東太平洋で上昇, 西太平洋で下降の東西循環が顕著に現われる。また, 中国大陸東部から西太平洋の 亜熱帯域にかけて，低気圧活動の活発化に対応した低気圧性循環の強まりが見られる。

主成分解析と合成図解析から，前論文（新田，1986）で見つけられた，雲量の西太平洋一日本間の振 動に伴う風の場を求めた。西部太平洋亜熱帯域 $\left(\sim 20^{\circ} \mathrm{N}\right)$ で対流活動が活発な時, そのや、北西側で 低気圧性循環が，また，日本を含む中緯度域で高気圧性循環が強化される。これらの変動は，熱帯域の 対流活動の活発化に伴う亜熱帯高気圧の北上に対応しており, 東アジア域の夏の天候に多大の影響を与 えているものと思われる。 